January $2003 \quad$ • NREL/TP-620-32742

\title{
Domestic Energy Scenarios
}

\section{J. Aabakken and W. Short}

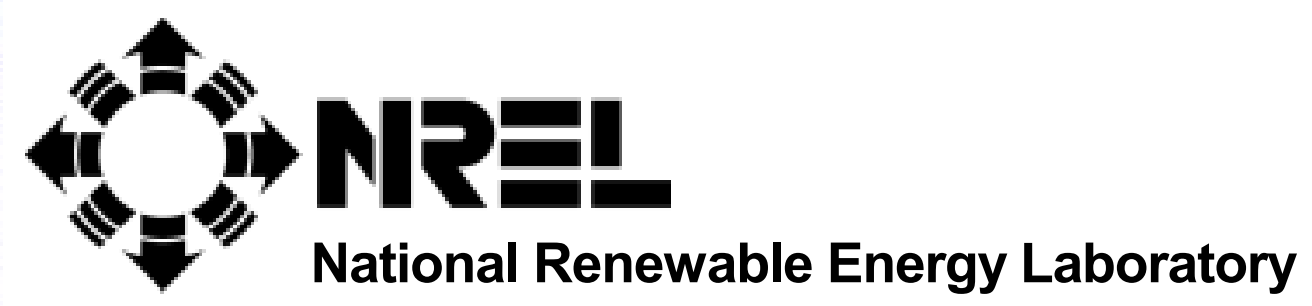

1617 Cole Boulevard

Golden, Colorado 80401-3393

NREL is a U.S. Department of Energy Laboratory

Operated by Midwest Research Institute $\bullet$ Battelle $\bullet$ Bechtel

Contract No. DE-AC36-99-G010337 


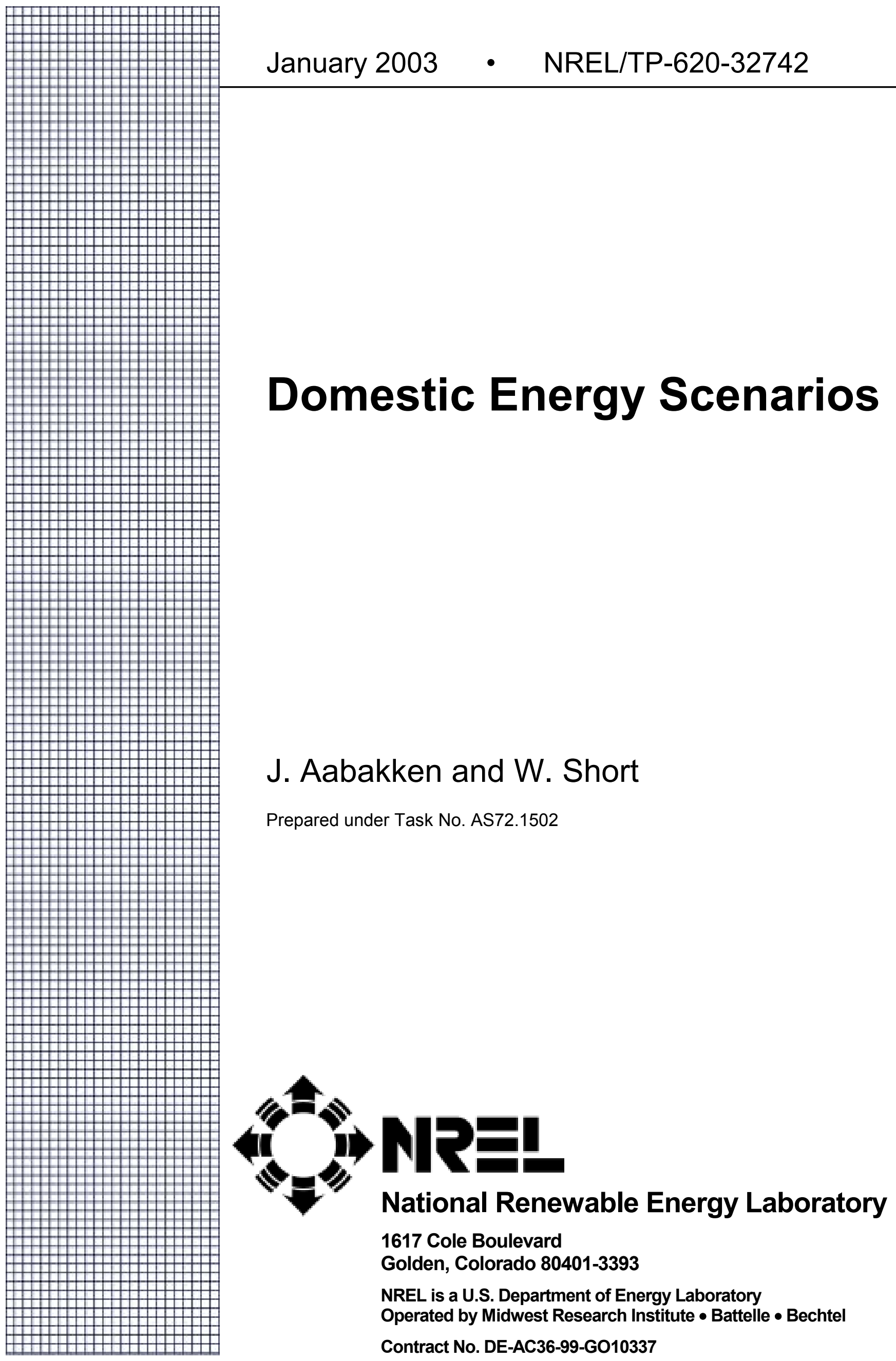




\section{NOTICE}

This report was prepared as an account of work sponsored by an agency of the United States government. Neither the United States government nor any agency thereof, nor any of their employees, makes any warranty, express or implied, or assumes any legal liability or responsibility for the accuracy, completeness, or usefulness of any information, apparatus, product, or process disclosed, or represents that its use would not infringe privately owned rights. Reference herein to any specific commercial product, process, or service by trade name, trademark, manufacturer, or otherwise does not necessarily constitute or imply its endorsement, recommendation, or favoring by the United States government or any agency thereof. The views and opinions of authors expressed herein do not necessarily state or reflect those of the United States government or any agency thereof.

Available electronically at http://www.osti.gov/bridge

Available for a processing fee to U.S. Department of Energy and its contractors, in paper, from:

U.S. Department of Energy

Office of Scientific and Technical Information

P.O. Box 62

Oak Ridge, TN 37831-0062

phone: 865.576 .8401

fax: 865.576.5728

email: reports@adonis.osti.gov

Available for sale to the public, in paper, from:

U.S. Department of Commerce

National Technical Information Service

5285 Port Royal Road

Springfield, VA 22161

phone: 800.553.6847

fax: 703.605.6900

email: orders@ntis.fedworld.gov

online ordering: http://www.ntis.gov/ordering.htm 


\section{Acknowledgments}

This work was funded by the U.S. Department of Energy's (DOE) Office of Energy Efficiency and Renewable Energy.

The authors wish to thank Susan H. Holte of the Office of Power Technologies in the U.S. Department of Energy's (DOE) Office of Energy Efficiency and Renewable Energy for her sponsorship and thoughtful review. The authors also wish to thank the following reviewers for their thoughtful comments and suggestions: Hill Huntington of Stanford Energy Modeling Forum, Morey Wolfson of NREL, and Frances Wood of OnLocation. Finally, the authors wish to thank Al Berger of NREL for research support and Michelle Kubik of NREL for her editorial review. 


\section{Introduction}

sce•nar $\bullet$ i॰o

an imagined or projected sequence of events, esp. any of several detailed plans or possibilities.

This report attempts to organize and evaluate scenarios of markets and technologies that could impact renewable and distributed electricity-generating technologies during the next 20-100 years in the United States. For the purposes of this report, scenarios are defined broadly as any projection or forecast that helps illuminate the potential of Renewable Electric Technologies (RETs) in the United States. Scenarios vary widely in terms of their scope - some focus on supply of fuels or narrow segments of markets with limited timeframes, while others are broader in scope and time span. Because the focus of this report is on domestic scenarios, broader regional and global scenarios are discussed here only if they contain information on future U.S. energy markets.

There are several factors that influence the market penetration of renewable energy and distributed generation technologies. Most notable among these are natural gas prices, technology improvements, and policy measures. Natural gas prices are important because most new generating capacity, as well as marginal generation units, generally are naturalgas fired. Assumptions about the rate of improvement in renewable and distributed generation technologies can also have a significant impact on market penetration. Finally, policy measures that support these technologies, such as tax credits or interconnection standards, can contribute to their accelerated adoption.

We focus in this report on those U.S. energy scenarios that explicitly consider these primary influences on market penetration. More particularly, we included scenarios that examine:

- The potential of Renewable Electric Technologies (RETs) in the United States during the next 100 years

- Overall U.S. energy use

- RET cost/performance improvements

- The development of competing conventional technologies

- Fossil fuel resource depletion and prices in the United States, especially natural gas

- Future environmental regulation

- Electric-sector restructuring

- Distributed generation development

- Electric demand growth (including major new loads like the Internet)

The first section of the report consists of general findings that summarize and synthesize information from all the scenarios covered in this report. A simple matrix indicates which areas each scenario covers. The second section provides brief summaries of relevant scenarios selected for this report. The section is divided into three parts - energy economy scenarios, technology forecast scenarios and distributed generation scenarios. A simple matrix indicates the areas covered by the specific scenario, including a brief 
description of the objective for the scenario, the modeling framework, and key findings. The third section is a collection of tables that summarizes the relevant information from the selected scenarios.

\section{General Findings}

The scenarios described in this report generally fall into two main groups: 1) policy reports that seek to analyze a specific set of policies, 2) technology and market forecast reports that tend to focus on the growth of certain segments of the energy market. The first category is more commonly performed by government and nongovernmental organizations (NGOs) attempting to analyze specific policies. Independent government agencies and industry trade associations usually publish the second category. It is therefore useful to take into account the differing motivations and assumptions that underpin each type of report, especially if comparisons are made among reports. Such a detailed comparison is beyond the scope of this report, which includes a brief summary of each scenario in the Scenario Profiles section. This report also lists key information from the different scenarios in a consistent form in the Scenario Summaries section.

The following matrix summarizes the area of focus for each scenario.

\begin{tabular}{|c|c|c|c|c|c|c|c|}
\hline $\begin{array}{l}\text { Scenario } \\
\text { Name* }^{*}\end{array}$ & $\begin{array}{l}\text { Energy } \\
\text { Use }\end{array}$ & $\begin{array}{l}\text { Energy } \\
\text { Prices }\end{array}$ & $\begin{array}{l}\text { Energy } \\
\text { Resources }\end{array}$ & $\begin{array}{l}\text { Technology } \\
\text { Improvement }\end{array}$ & $\begin{array}{l}\text { Distributed } \\
\text { Generation }\end{array}$ & Restructuring & $\begin{array}{l}\text { Environmental } \\
\text { Regulations }\end{array}$ \\
\hline 1) AEO 2002 & $x$ & $x$ & $x$ & $x$ & $x$ & $x$ & $x$ \\
\hline 2) EIA- RPS & $x$ & $x$ & & & & $x$ & $x$ \\
\hline 3) EIA-Gas & & $x$ & $x$ & & & & \\
\hline 4) EIA-Deplete & $x$ & $x$ & $x$ & & & & \\
\hline 5) EIA-MEC & $x$ & $x$ & & $x$ & & & $x$ \\
\hline 6) $\mathrm{CEF}$ & $x$ & $x$ & $x$ & $x$ & $x$ & $x$ & $x$ \\
\hline 7) $\mathrm{GRI}$ & $x$ & $x$ & $x$ & & & & \\
\hline 8) EPIA & $x$ & & $x$ & & & & \\
\hline 9) UCS-CEB & $x$ & $x$ & $x$ & $x$ & & $x$ & $x$ \\
\hline 10) UCS-RPS & $x$ & $x$ & & & & & $x$ \\
\hline 11) EPI/CSE & $x$ & & & & & & $x$ \\
\hline 12) EMF & $x$ & $x$ & & & & $x$ & $x$ \\
\hline 13) IPAA & $x$ & $x$ & $x$ & & & & \\
\hline 14) $A G A$ & $x$ & & $x$ & & & & \\
\hline 15) LBNL & & & & & $x$ & $x$ & \\
\hline 16) $R E$ & $x$ & & & & & $x$ & \\
\hline
\end{tabular}

* Numbers correspond to studies profiled on pages 5-16.

\section{Time frames}

In general, fewer scenarios are available the further out the time frame of the scenario. Most scenarios cover only the near term, i.e., the next 20 years or so. There is a distinct lack of models that venture beyond 20 years into the future. This seems to be due to a combination of factors, such as limitations in modeling technology or the needs of the organization producing the scenario. Some scenarios do not provide a specific time frame. 
Several of the scenarios employ the National Energy Modeling System (NEMS) model for their analysis. This model, developed and maintained by the Energy Information Administration (EIA), is used to develop projections 20 years into the future. If longerterm scenarios beyond 20 years are to be investigated, other models must be employedor the NEMS model must be modified to accommodate such time frames.

\section{Distributed Generation}

Some scenarios indicate that distributed generation (DG) is poised to experience growth in the future. Transmission constraints and system reliability concerns are cited as drivers for a move toward distributed power systems. In general, other than the EIA's Annual Energy Outlook, none of the studies cover both distributed generation and renewables specifically.

\section{Renewable Energy Characterization}

Where the scenarios are developed using the NEMS model-which includes a full slate of renewable energy technologies - renewables are frequently included explicitly in the scenarios. However, those scenarios developed by the conventional technology/fuels trade associations usually include at best only a small subset of renewable energy technologies, e.g. biomass and wind.

The cost and performance of renewable energy in the scenarios show no discrete breakthroughs or novel technologies. Most rely on the renewable energy technology characterizations of NEMS or the Electric Power Research Institute (EPRI)/Department of Energy (DOE) technology characterizations report (EPRI/DOE 1997).

\section{Technology Improvement}

Among the scenarios covered in this report, there is more emphasis on policies to accelerate renewable generating technologies and market penetration than studies of $\mathrm{R} \& \mathrm{D}$ impacts on cost reductions and/or efficiency improvements. Some scenarios indicate there is far greater uncertainty regarding future cost reductions and efficiency improvements for renewable technologies than responses to policies. As projections are made further into the future, the uncertainty around technology costs widen considerably.

While most scenarios make assumptions about different levels of improvement in cost and efficiency, no scenarios project any "surprise" technologies in the future.

\section{Policy Initiatives}

Environmental Benefits

Only two studies, one by Union of Concerned Scientists (UCS) ${ }^{1}$ and one by the EIA ${ }^{2}$, focus specifically on reductions of criteria pollutants and develop several related scenarios, while several studies and their scenarios focus on global climate-change

\footnotetext{
${ }^{1}$ Union of Concerned Scientists, Clean Energy Blueprint - A Smarter National Energy Policy for Today and the Future.

${ }^{2}$ EIA, Analysis of Strategies for Reducing Multiple Emissions from Electric Power Plants with Advanced Technology Scenarios.
} 
mitigation. One study, the Scenarios for a Clean Energy Future, deals specifically with renewables and clean air policies, with an emphasis on climate-change mitigation. The Clean Energy Blueprint by UCS covers both climate change and criteria pollutants.

\section{Energy Security}

There is little emphasis on energy security and renewables. No scenario deals specifically with renewables and energy security.

\section{Modeling Issues}

As different scenarios rely on results from many different computer models, it is worth mentioning some of the factors that should be considered when comparing the different scenarios.

\section{Reliance on NEMS}

Several of the scenarios summarized in this report rely on the NEMS model or some variation of the NEMS model. Other models rely on data from NEMS or are "calibrated" to NEMS in some respect. This may be a matter of convenience or an effort to lend credibility to any new scenario. Certainly this facilitates comparisons among different scenarios, as long as the differing assumptions are disclosed and well understood. Among the models included in this report, NEMS appears to be the most widely used and referenced. This is partly due to NEMS being publicly available, while other models (and scenarios based on other models) may be proprietary or attainable only for a fee and therefore inaccessible to this study.

\section{Lack of transparency}

While the NEMS model is documented and many assumptions in it are published, other models developed by consulting firms or trade associations are proprietary and have very limited public disclosure of the inner workings and assumptions of the model.

Further efforts, such as those performed by the Stanford Energy Modeling Forum (EMF) to benchmark different models and compare them side-by-side, are useful in critically evaluating and comparing different scenarios.

\section{Apples and Oranges}

There are many diverse scenarios of the future. Any comparison needs to take into account the widely differing analytical underpinnings, assumptions, scope, time frames, and motivations behind each scenario. Some studies and their featured scenarios use models of the entire energy economy, and are used to address a broad scope of issues. Other studies feature scenarios that are limited to only one or two values and a limited time frame.

\section{Incremental Scenarios}

All the scenarios covered in this paper tend to involve incremental variations of their central theme. Because many rely on the same models and assumptions, the results are increments around a theme such as the EIA's Annual Energy Outlook. Granted, over 
time, even incremental changes can add up to major impacts during a decade or two, but they do so largely along a predictable path.

We could find no "surprise" scenarios that offer "inflection points" in the future that may indicate major changes in the future of the energy economy. A historical example of such a major change would be the rapid rise and subsequent leveling off of nuclear power in the United States. It is conceivable that similar dramatic inflection points may occur in the future. The causes of such inflection points can be many: major policy changes, natural disasters, the advent of economically competitive technology, unforeseen environmental impacts, etc.

Given the lack of sharp departures from the status quo, it may be valuable for the federal government to develop "surprise" scenarios that are linked to areas of strategic interest to the nation. For example, alternative economic growth paths that also involve major changes in the economy's structure, away from energy-intensive sectors. More specific scenarios could focus on changes in electricity pricing including dynamic (real-time) pricing or shifts away from postage-stamp transmission pricing toward nodal pricing. A more extreme example could be a scenario that assumes a major disruption in oil markets due to instability in the Middle East, Russia, or Venezuela. Another example would be an unforeseen climatic event that validates climate-change theories and mobilizes international efforts to significantly reduce greenhouse gas emissions by 2020 .

\section{Scenario Profiles}

There are two groups of scenarios: 1) Energy economy scenarios, which look at the energy economy in the United States as a whole, focusing on changes in market conditions that may influence energy use and market penetration of different energy generation technologies. 2) Technology scenarios, which focus on the specifics of technology improvement in terms of changes in capital and operating costs and the performance of the different technologies.

There are several distinct energy economy scenarios that are covered in this report. They are numbered for convenience, with publishing organizations grouped together. The order does not imply any ranking or significance of any of the scenarios.

\section{Energy Economy Scenarios}

Scenarios that cover the energy economy are contained in the following reports and studies. Each study or report may contain one or more scenarios.

\section{1) Annual Energy Outlook 2002}

Publishing Organization: Energy Information Administration (EIA)

\begin{tabular}{|l|l|l|l|l|l|l|}
\hline Energy Use & Energy Prices & $\begin{array}{l}\text { Energy } \\
\text { Resources }\end{array}$ & $\begin{array}{l}\text { Technology } \\
\text { Improvement }\end{array}$ & $\begin{array}{l}\text { Distributed } \\
\text { Generation }\end{array}$ & Restructuring & $\begin{array}{l}\text { Environmental } \\
\text { Regulations }\end{array}$ \\
\hline $\mathrm{x}$ & $\mathrm{x}$ & $\mathrm{x}$ & $\mathrm{x}$ & $\mathrm{x}$ & $\mathrm{x}$ & $\mathrm{X}$ \\
\hline
\end{tabular}


Published annually, the Annual Energy Outlook (AEO2002) provides a broad overview of energy consumption, technology improvement, energy prices, and policy implications for the United States.

The AEO2002 uses the National Energy Modeling System (NEMS) to model and project energy use in the United States. The NEMS model has been used by organizations to evaluate alternative scenarios, while others use NEMS assumptions and results as inputs in their own models. The scenarios presented in the AEO2002, and earlier editions of AEO, especially the reference case, are often used as a benchmark for other studies as well as other models.

The AEO2002 features several scenarios, or side cases that focus on differing assumptions about technological progress, resource availability, and policy measures. In the reference case, the AEO2002 projects that during the next 20 years, new capacity additions will be dominated by natural gas-generating technologies along with low natural gas prices. Coal will continue as a dominant generating technology due to inexpensive coal. In the reference scenario, non-hydro renewables are projected to increase only slightly, only contributing 4 percent of added capacity through 2020 . Biomass, especially cogeneration, is projected to see the largest absolute growth. Geothermal is also projected to increase; and wind will increase to a lesser degree. Solar power is not expected to contribute to new generating capacity at any significant level. While the vast majority of new capacity additions are projected to be central generating station technologies, about 19 gigawatts, or about 5 percent (compared to a total of 355 gigawatt (GW)) of distributed generating capacity is projected to be added by 2020 .

Time frame: 2002-2020

Publication Date: December 2001

2) Impacts of a 10-Percent Renewable Portfolio Standard

Publishing Organization: Energy Information Administration (EIA), requestor: Senator Frank Murkowski.

\begin{tabular}{|l|l|l|l|l|l|l|}
\hline Energy Use & Energy Prices & $\begin{array}{l}\text { Energy } \\
\text { Resources }\end{array}$ & $\begin{array}{l}\text { Technology } \\
\text { Improvement }\end{array}$ & $\begin{array}{l}\text { Distributed } \\
\text { Generation }\end{array}$ & Restructuring & $\begin{array}{l}\text { Environmental } \\
\text { Regulations }\end{array}$ \\
\hline $\mathrm{X}$ & $\mathrm{X}$ & & & $\mathrm{X}$ & $\mathrm{X}$ \\
\hline
\end{tabular}

This report analyzes the impacts of implementing a 10 percent renewable portfolio standard (RPS) for electricity generation in the United States. A second scenario of a 20 percent RPS also is presented.

The report uses the NEMS model to project the impacts of implementing a 10 percent renewable portfolio standard and a second scenario with a 20 percent RPS.

Generators failing to meet RPS standards will face a 3-cent per kilowatt-hour penalty.

In both the 10 percent and 20 percent RPS scenarios, electricity generators will fail to achieve the respective goals. Generators are projected to achieve 8.4 and 12 percent, respectively, of qualifying renewable electricity generation. The remaining generators are 
projected to pay the penalty of 3 cents per kilowatt-hour rather than invest in new renewable generating capability. The scenario also projects that there will be no net increase in consumers' energy bills due to the fact that the RPS lowers natural gas demand and prices.

Time frame: 2002-2020

Publication Date: February 2002

3) U.S. Natural Gas Markets: Recent Trends and Prospects for the Future

Publishing Organization: Energy Information Administration (EIA), requestor: Secretary of Energy Spencer Abraham.

\begin{tabular}{|l|l|l|l|l|l|l|}
\hline Energy Use & Energy Prices & $\begin{array}{l}\text { Energy } \\
\text { Resources }\end{array}$ & $\begin{array}{l}\text { Technology } \\
\text { Improvement }\end{array}$ & $\begin{array}{l}\text { Distributed } \\
\text { Generation }\end{array}$ & Restructuring & $\begin{array}{l}\text { Environmental } \\
\text { Regulations }\end{array}$ \\
\hline $\mathrm{X}$ & $\mathrm{X}$ & $\mathrm{X}$ & & & \\
\hline
\end{tabular}

This report by the EIA makes projections about short-term and midterm outlook for natural gas in the United States. Development of the scenarios is done with the NEMS model and is based largely on the AEO2001 with some updated assumptions.

In the reference case based on Annual Energy Outlook 2001 (AEO2001), consumption of natural gas is projected to increase to 31.6 trillion cubic feet in 2015 and 34.7 trillion cubic feet in 2020. Natural gas consumption in the alternate scenarios ranges from a low of 31.2 trillion cubic feet ("Low Resource" scenario) to a high of 36.0 trillion cubic feet ("High Resource" scenario). By 2020, the projected natural gas real price in the reference case is $\$ 3.13$ per thousand cubic feet. The alternate scenarios have prices as low as $\$ 2.50$ per thousand cubic feet ("Rapid Technology" scenario) and as high as $\$ 4.53$ per thousand cubic feet ("Low Resource" scenario).

Time frame: 2000-2020

Publication Date: May 2001

4) Accelerated Depletion: Assessing Its Impact on Domestic Oil and Natural Gas Prices and Production Publishing Organization: Energy Information Administration (EIA), requestor: Office of Fossil Energy, U.S. Department of Energy (DOE).

\begin{tabular}{|l|l|l|l|l|l|l|}
\hline Energy Use & Energy Prices & $\begin{array}{l}\text { Energy } \\
\text { Resources }\end{array}$ & $\begin{array}{l}\text { Technology } \\
\text { Improvement }\end{array}$ & $\begin{array}{l}\text { Distributed } \\
\text { Generation }\end{array}$ & Restructuring & $\begin{array}{l}\text { Environmental } \\
\text { Regulations }\end{array}$ \\
\hline $\mathrm{X}$ & $\mathrm{X}$ & $\mathrm{X}$ & & & $\mathrm{X}$ \\
\hline
\end{tabular}

This report presents several scenarios on the effects of different assumptions for depletion of natural gas and petroleum resources in the United States. Several scenarios are evaluated with varying levels of accelerated depletion of reserves. It is assumed that each new discovery adds incrementally fewer resources over time. In addition, varying assumptions about technology, access to resources in the Rocky Mountain region, and increased imports are evaluated. 
The scenarios are developed with the AOE2000 version of the NEMS model. Different assumptions for alternate cases are made regarding the pace of depletion, technological growth, reduced environmental constraints for the region, and greater levels of imports.

The results indicate that accelerated depletion of resources leads to higher prices (as high as $\$ 4.56$ per thousand cubic feet versus the reference price of $\$ 2.79$ per thousand cubic feet by 2020) and lower levels of production. By 2020, natural gas production is projected to be 13 percent lower under accelerated depletion than in the reference case. Assumptions about higher petroleum prices also lead to significantly higher natural gas prices ( $\$ 4.40$ per thousand cubic feet versus the reference price of $\$ 2.79$ by 2020 ). A combination of increased access to Rocky Mountain areas combined with faster introduction of new technology may offset the effects of accelerated depletion.

Time frame: $2000-2020$

Publication Date: July 2000

\section{5) Analysis of Strategies for Reducing Multiple Emissions from Electric Power} Plants with Advanced Technology Scenarios

Publishing Organization: Energy Information Administration (EIA), requestors: Senators James M. Jeffords and Joseph I. Lieberman.

\begin{tabular}{|l|l|l|l|l|l|l|}
\hline Energy Use & Energy Prices & $\begin{array}{l}\text { Energy } \\
\text { Resources }\end{array}$ & $\begin{array}{l}\text { Technology } \\
\text { Improvement }\end{array}$ & $\begin{array}{l}\text { Distributed } \\
\text { Generation }\end{array}$ & Restructuring & $\begin{array}{l}\text { Environmental } \\
\text { Regulations }\end{array}$ \\
\hline $\mathrm{X}$ & $\mathrm{x}$ & & $\mathrm{x}$ & $\mathrm{X}$ & $\mathrm{X}$ & $\mathrm{x}$ \\
\hline
\end{tabular}

This special report presents scenarios of reducing multiple criteria pollutants from fossilfueled electricity generators. Two sets of scenarios are presented: "cases without emission limits" and "cases with emission limits."

A modified version of the NEMS model is used for the scenarios presented. Some scenarios use modifications of the NEMS model that are consistent with the moderate and advanced policy cases in the Scenarios for a Clean Energy Future (CEF), including a renewable portfolio standard. Assumptions are made for different levels of emission caps, and emission prices for $\mathrm{CO} 2, \mathrm{SO} 2, \mathrm{NOx}$, and $\mathrm{Hg}$ are projected.

All of the scenarios presented, both with and without emission limits, lead to a decline in primary energy consumption and electricity consumption. Emissions of $\mathrm{CO} 2$ are reduced with large reductions in the emissions of $\mathrm{SO} 2, \mathrm{NOx}$, and $\mathrm{Hg}$. Natural gas-fired electricity generation is projected to increase with resulting higher natural gas prices. Coal-fired generation is projected to decrease, especially in cases with a carbon tax. In the reference case with emissions limits, the price of electricity increases by 33 percent in 2020, compared to the reference case without emissions limits. As a result of this, gross domestic product is projected to decline slightly. The introduction of the emissions limits raises the projected average delivered price of electricity by 33 percent by 2020 compared to the reference case. Energy expenditures are projected to be higher than in the reference case without emission limits. However, in the advanced technology case, energy expenditures are lower due to more energy-efficient technologies and lower fossil 
fuel and electricity prices. Distributed generation capacity is projected to be $11 \mathrm{GW}$ by 2020 in the reference case, and lower in all other cases, with only 1.8 GW projected in the Advanced Technology with Emission Limits scenario.

Imposition of emission limits leads to increased renewable electricity generation from 399 billion $\mathrm{kWh}$ to 519 billion $\mathrm{kWh}$ in 2020. The "Advanced Technology" case results in similar increases from 409 million $\mathrm{kWh}$ (without emission limits) to 524 million $\mathrm{kWh}$ (with emission limits) in 2020. In the advanced technology case, the cost of compliance is lower, based on a lower baseline of energy and emissions.

Time frame: $2000-2020$

Publication Date: October 2001

6) Scenarios for a Clean Energy Future

Publishing Organization: Interlaboratory Working Group (IWG)

\begin{tabular}{|l|l|l|l|l|l|l|}
\hline Energy Use & Energy Prices & $\begin{array}{l}\text { Energy } \\
\text { Resources }\end{array}$ & $\begin{array}{l}\text { Technology } \\
\text { Improvement }\end{array}$ & $\begin{array}{l}\text { Distributed } \\
\text { Generation }\end{array}$ & Restructuring & $\begin{array}{l}\text { Environmental } \\
\text { Regulations }\end{array}$ \\
\hline $\mathrm{x}$ & $\mathrm{x}$ & $\mathrm{x}$ & $\mathrm{x}$ & $\mathrm{x}$ & $\mathrm{x}$ & $\mathrm{x}$ \\
\hline
\end{tabular}

The Scenarios for a Clean Energy Future (CEF) study explores what can happen if alternative policies favorable to renewables and energy efficiency are pursued. Four scenarios are explored: a business as usual, a moderate scenario, and two advanced scenarios with carbon taxes of $\$ 25$ per ton and $\$ 50$ per ton respectively.

The scenarios presented in CEF are developed using a modified version of the EIA's NEMS model. Different assumptions are made on policies to tighten standards for buildings, industry, transportation, and electricity generation. Electric generators are projected to face a renewable portfolio standard (in the advanced scenarios) and electricindustry restructuring. The advanced scenario also assumes a doubling of federal R\&D for renewable and energy efficiency technologies, and a domestic carbon-trading system.

The policy measures and technology improvement assumptions made in the study are projected to result in significant reductions of all emissions, reduced reliance on petroleum, and more efficient use of, and generation of, electricity. These ends are accomplished with no increase in consumer energy bills. Distributed generation is limited to industrial use of combined heat and power, and photovoltaics.

Time frame: $2000-2020$

Publication Date: October 2001

7) 2000 Edition of the GRI Baseline Projection of the U.S. Energy Supply and Demand to 2015 Publishing Organization: Gas Research Institute (GRI)

\begin{tabular}{|l|l|l|l|l|l|l|}
\hline Energy Use & Energy Prices & $\begin{array}{l}\text { Energy } \\
\text { Resources }\end{array}$ & $\begin{array}{l}\text { Technology } \\
\text { Improvement }\end{array}$ & $\begin{array}{l}\text { Distributed } \\
\text { Generation }\end{array}$ & Restructuring & $\begin{array}{l}\text { Environmental } \\
\text { Regulations }\end{array}$ \\
\hline $\mathrm{x}$ & $\mathrm{x}$ & $\mathrm{x}$ & & & & \\
\hline
\end{tabular}


This report by GRI makes projections about energy demand, energy prices, and energy supply through 2015. Projections are made for the United States on a national level and at the regional level. No policy measures are evaluated.

GRI uses a collection of models for its projections: ISTUM (a proprietary model by EEA), the GRI Energy Demand Model (which is based on NEMS), Hydrocarbon Supply Model (HSM), and Gas Market and Data Forecasting System (GMDFS). In addition, GRI relies on two outside models: DRI Macroeconomic Model and Hill \& Associates Coal Model.

GRI projects that primary energy consumption will increase to 117.7 quadrillion British Thermal Units (Btu) by 2015, lower than the AEO2002 reference case of 123.6 quadrillion Btu. Natural gas demand is projected to increase steadily to 33.7 quadrillion Btu by 2015. Independent power generators are projected to increase to produce more than a third of all electricity by 2015 . Natural gas prices are projected to trend downward through 2015.

The scenario emphasizes natural gas and coal resources, with little attention to renewable energy. Renewable energy consumption is projected to be 5.6 quadrillion Btu by 2015, considerably lower than AEO2002. In the electric-power sector, hydropower is projected to remain around current levels, while non-hydro renewables are projected to increase from 0.61 quadrillion Btu in 1998 to 2.45 quadrillion Btu in 2015. Distributed generation is not addressed in this scenario.

Time frame: 2000-2015

Publication Date: December 2000

8) Solar Generation: electricity for over 1 billion people and 2 million jobs by 2020 Publishing Organization: Greenpeace/European Photovoltaic Industry Association (EPIA)

\begin{tabular}{|l|l|l|l|l|l|l|}
\hline Energy Use & Energy Prices & $\begin{array}{l}\text { Energy } \\
\text { Resources }\end{array}$ & $\begin{array}{l}\text { Technology } \\
\text { Improvement }\end{array}$ & $\begin{array}{l}\text { Distributed } \\
\text { Generation }\end{array}$ & Restructuring & $\begin{array}{l}\text { Environmental } \\
\text { Regulations }\end{array}$ \\
\hline $\mathrm{X}$ & & $\mathrm{x}$ & & & & \\
\hline
\end{tabular}

This report focuses on the worldwide potential for growth in the global photovoltaics (PV) market. The main finding is a scenario by 2020 with PV generating $276 \mathrm{TWh}$ of electricity. By 2040, PV is projected to generate 9,113 TWh.

No information is provided on the modeling framework. Distributed generation is not specifically addressed in this scenario.

Market growth rates are based on recent developments and assume the same level of growth during the time span of the scenario. Globally, the average growth rate for PV is assumed to be 27 percent per year through 2009 and then increasing by 34 percent per year between 2010 and 2020. Another assumption is the continuation of national and 
regional market support programs, national targets for PV installations, solar radiation potential, availability of rooftop area, and demand in off-grid segments.

For the United States, two separate scenarios are presented: 1) "business as usual" (BAU) and 2) "take-off scenario" (TOS). In the BAU case, total added generating capacity is projected to reach $843.43 \mathrm{MW}$ by 2020 . The TOS, which assumes the United States adopts a nationwide support scheme similar to those in Germany and Japan, projects 23.4 $\mathrm{GW}$ by 2020 . Annual unit sales could reach $\$ 1,700$ and $\$ 27,573$ million per year, respectively.

Time frame: 2000-2040

Publication Date: September 2001

9) Clean Energy Blueprint - A Smarter National Energy Policy for Today and the Future

Publishing Organization: Union of Concerned Scientists, with American Council for an Energy-Efficient Economy and Tellus Institute.

\begin{tabular}{|l|l|l|l|l|l|l|}
\hline Energy Use & Energy Prices & $\begin{array}{l}\text { Energy } \\
\text { Resources }\end{array}$ & $\begin{array}{l}\text { Technology } \\
\text { Improvement }\end{array}$ & $\begin{array}{l}\text { Distributed } \\
\text { Generation }\end{array}$ & Restructuring & $\begin{array}{l}\text { Environmental } \\
\text { Regulations }\end{array}$ \\
\hline $\mathrm{x}$ & $\mathrm{x}$ & $\mathrm{x}$ & $\mathrm{x}$ & & $\mathrm{x}$ & $\mathrm{x}$ \\
\hline
\end{tabular}

This report investigates several policy options to create a cleaner energy system. Included in the study are renewable portfolio standard (RPS), public benefits fund, net metering, production tax credit, increased R\&D funding for renewables, combined heat and power, improved efficiency standards, enhanced building codes, tax incentives, and industrial energy efficiency measures.

This report uses the National Energy Modeling System (NEMS) to investigate the potential future impacts of several policy initiatives. The modified NEMS model used in the Scenarios for a Clean Energy Future was used as a starting point for the analysis. Assumptions about renewables were changed for wind, geothermal, solar, and biomass. The Clean Energy Blueprint compares the "business as usual" scenario (based on the EIA's Annual Energy Outlook 2001) with its own Clean Energy Blueprint scenario and a subset of these policies included in the Renewable Energy and Energy Efficiency Investment Act of 2001 (S. 1333).

The Clean Energy Blueprint scenario leads to a dramatic increase in renewable energy along with a decrease in fossil fuels and nuclear power. At least 20 percent of electricity can be produced by non-hydro renewables by 2020 . The use of natural gas can be reduced 31 percent, and use of coal can be reduced 60 percent compared to business as usual by 2020. At the same time, consumers are estimated to save $\$ 440$ billion by 2020 . Distributed generation is not specifically addressed in this scenario.

Time frame: $2000-2020$

Publication Date: October 2001 
10) A Powerful Opportunity - Making Renewable Electricity the Standard Publishing Organization: Union of Concerned Scientists (UCS)

\begin{tabular}{|l|l|l|l|l|l|l|}
\hline Energy Use & Energy Prices & $\begin{array}{l}\text { Energy } \\
\text { Resources }\end{array}$ & $\begin{array}{l}\text { Technology } \\
\text { Improvement }\end{array}$ & $\begin{array}{l}\text { Distributed } \\
\text { Generation }\end{array}$ & Restructuring & $\begin{array}{l}\text { Environmental } \\
\text { Regulations }\end{array}$ \\
\hline $\mathrm{x}$ & $\mathrm{x}$ & & & & $\mathrm{x}$ \\
\hline
\end{tabular}

This report examines the prospects of several different levels of non-hydro renewable portfolio standards (RPS) electricity generation. These standards range from 4 percent to 20 percent renewable electricity generation by 2020 .

The analysis uses an electricity market model called RenewMarket. This model is patterned after the Electricity Capacity Planning sub-module of the National Energy Modeling System (NEMS) model.

The study finds that, under all scenarios, average electricity prices for consumers fall by between 13 to 17 percent between 1997 and 2020. At the same time, every RPS scenario would provide environmental benefits, reduce $\mathrm{CO} 2$ emissions, diversify the electricitygenerating portfolio, and expand renewable energy development. In addition, decreased demand for natural gas for electricity generation would result in lower natural gas prices. Distributed generation is not specifically addressed in this scenario.

Time frame: $2000-2030$

Publication Date: January 1999

\section{1) Clean Energy and Jobs - A Comprehensive Approach to Climate Change and}

Energy Policy

Publishing Organization: Economic Policy Institute (EPI) and Center for a Sustainable Economy (CSE)

\begin{tabular}{|l|l|l|l|l|l|l|}
\hline Energy Use & Energy Prices & $\begin{array}{l}\text { Energy } \\
\text { Resources }\end{array}$ & $\begin{array}{l}\text { Technology } \\
\text { Improvement }\end{array}$ & $\begin{array}{l}\text { Distributed } \\
\text { Generation }\end{array}$ & Restructuring & $\begin{array}{l}\text { Environmental } \\
\text { Regulations }\end{array}$ \\
\hline $\mathrm{X}$ & & & & & & $\mathrm{x}$ \\
\hline
\end{tabular}

This report uses the LIFT (Long-term Interindustry Forecasting Tool) model, which is a 97-sector inter-industry macroeconomic model created by the Inforum modeling group. The model was calibrated to the 2001 Annual Energy Outlook. In addition, the scenario assumes carbon taxes, as well as energy efficiency improvements, from the Scenarios for Clean Energy Future (CEF) report.

The macroeconomic scope and emphasis of this report is on carbon emission reductions and job creation. The scenario projects that GDP will increase slightly compared to the baseline scenario. While energy prices overall are projected to increase, expenditures for energy are projected to fall as consumers switch to more energy-efficient technologies.

This scenario assumes that the proposed renewable energy portfolio standard be structured to encourage renewable generation by existing utilities, as opposed to independent power producers. The policy package for renewables also includes a more 
aggressive form of the renewable portfolio standard, which increases to 10 percent by 2010 and 20 percent in 2020. Distributed generation is not specifically addressed in this scenario.

Time frame: $2000-2020$

Publication Date: 2002

12) Prices and Emissions in a Restructured Electricity Market

Publishing Organization: Energy Modeling Forum (EMF), Stanford University

\begin{tabular}{|l|l|l|l|l|l|l|}
\hline Energy Use & Energy Prices & $\begin{array}{l}\text { Energy } \\
\text { Resources }\end{array}$ & $\begin{array}{l}\text { Technology } \\
\text { Improvement }\end{array}$ & $\begin{array}{l}\text { Distributed } \\
\text { Generation }\end{array}$ & Restructuring & $\begin{array}{l}\text { Environmental } \\
\text { Regulations }\end{array}$ \\
\hline $\mathrm{X}$ & $\mathrm{x}$ & & & $\mathrm{x}$ & $\mathrm{x}$ \\
\hline
\end{tabular}

This report compares and summarizes results from several different models. The models included in the study are National Modeling Energy System (NEMS), by the Energy Information Administration; Policy Office Electricity Modeling System (POEMS), by the U.S. Department of Energy and OnLocation, Inc.; Haiku, by Resources for the Future (RFF); IPM, by the U.S. Environmental Protection Agency (EPA) and ICF Consulting, Inc.; Energy 2020, by Canadian Energy Research Institute; and MarketPoint, by Altos Management Partners.

All models were run using a set of five standardized scenarios that assume immediate deregulation of the electricity industry. The scenarios evaluated are: "reference case," "high demand," "low natural gas prices," "expanded transmission," and a "renewable portfolio standard (RPS)." The reference case is based on the 1999 Annual Energy Outlook (AEO1999).

Results indicate differences among the models. Although results were fairly consistent in the reference case, the models tended to diverge in the more extreme scenarios. Total fuel consumption varies from a high of 36.3 quadrillion Btu (NEMS) to a low of 33.2 quadrillion Btu (E2020) by 2010. In the baseline scenario, natural gas-fired generators account for 84 to 98 percent of cumulative additions by 2010. While two models (NEMS and POEMS), project non-hydro electricity to increase by 33-48 percent by 2010 , renewables capacity remains a small share of the total. The baseline scenario assumes the wind tax credit is extended to 2005. By 2010, coal still is the dominant fuel. The different models diverge significantly in terms of cumulative combined-cycle capacity additionsranging from a low of around 55 gigawatts (NEMS) to 190 gigawatts (E2020) by 2010. Wholesale prices also vary widely among the models. In some regions, the differences between models are up to $\$ 15$ per MWh by 2010 . There also are significant differences in interregional trade of electricity.

For renewables, only NEMS, POEMS, and RFF show details on capacity. While NEMS and POEMS are similar with about $2.3 \mathrm{GW}$ in cumulative additions, RFF projects about $0.2 \mathrm{GW}$ of new wind by 2010. In terms of geothermal, POEMS projects about $0.7 \mathrm{GW}$, while NEMS projects about $0.4 \mathrm{GW}$. For MSW, the roles are reversed-NEMS projects about $1.7 \mathrm{GW}$ while POEMS projects $0.4 \mathrm{GW}$. There are similar differences for biomass 
and solar. In the "low gas" scenario, the POEMS model projects nearly 60 percent less wind-generating capacity compared to the baseline scenario by 2010. Distributed generation is not specifically addressed in these scenarios.

Time frame: $2000-2010$

Publication Date: May 2001

13) Report of the IPAA Supply and Demand Committee - Long-Run Forecast (2001-2015)

Publishing Organization: Independent Petroleum Association of America (IPAA)

\begin{tabular}{|l|l|l|l|l|l|l|}
\hline Energy Use & Energy Prices & $\begin{array}{l}\text { Energy } \\
\text { Resources }\end{array}$ & $\begin{array}{l}\text { Technology } \\
\text { Improvement }\end{array}$ & $\begin{array}{l}\text { Distributed } \\
\text { Generation }\end{array}$ & Restructuring & $\begin{array}{l}\text { Environmental } \\
\text { Regulations }\end{array}$ \\
\hline $\mathrm{X}$ & $\mathrm{x}$ & $\mathrm{x}$ & & & \\
\hline
\end{tabular}

The IPAA study presents projections of general macroeconomic trends, natural gas, and petroleum supply and demand.

No information is disclosed about the modeling framework. The IPAA Supply \& Demand Committee performs the projections. The projections seem to rely in part on historical data from the Energy Information Administration (EIA).

GDP is projected to grow by 3 percent per year through 2015, and energy consumption by 2.3 percent per year, resulting in a total energy consumption of 116.26 quadrillion Btu by 2015 - which is roughly 7 quadrillion Btu less than the AEO2002.

This scenario groups hydro and geothermal energy together, but no other renewables are mentioned. The IPAA projects that these renewables will increase by an average of 1.4 percent per year through 2015. The emphasis is on petroleum and natural gas. Consumption of natural gas is projected to increase by 1.8 percent per year, to 30,748 billion cubic feet by 2015 . The scenario does not project prices. Distributed generation is not specifically addressed in this scenario.

Time frame: 2001-2015

Publication Date: April 2001

14) Fueling the Future - Natural Gas and New Technologies for a Cleaner 21st Century

Publishing Organization: Washington Policy and Analysis, Inc., for American Gas Association (AGA)

\begin{tabular}{|l|l|l|l|l|l|l|}
\hline Energy Use & Energy Prices & $\begin{array}{l}\text { Energy } \\
\text { Resources }\end{array}$ & $\begin{array}{l}\text { Technology } \\
\text { Improvement }\end{array}$ & $\begin{array}{l}\text { Distributed } \\
\text { Generation }\end{array}$ & Restructuring & $\begin{array}{l}\text { Environmental } \\
\text { Regulations }\end{array}$ \\
\hline $\mathrm{X}$ & & $\mathrm{x}$ & & & & \\
\hline
\end{tabular}

This report presents two scenarios for natural gas use in the United States. The first scenario projects an increase in natural gas consumption to reach a total of 29.7 
quadrillion Btu by 2020 . The other scenario calls for greater use of natural gas, reaching a total of 35.5 quadrillion Btu by 2020 .

Modeling is done with the Washington Policy and Analysis (WPA) U.S. Energy Model. The WPA is a global model, with the United States representing a segment of the global energy economy.

The accelerated gas-use scenario makes assumptions about environmental and energy policy, including increased $R \& D$, few restrictions on access to natural gas resources, and a deregulated energy market where natural gas can compete. The scenario does not address natural gas prices. Renewable energy and distributed generation are not specifically addressed in this scenario.

Time frame: 1997-2020

Publication Date: February 2000

15) The Federal Role in Electric System R\&D During a Time of Transition: An Application of Scenario Analysis

Publishing Organization: Lawrence Berkeley National Laboratory

\begin{tabular}{|l|l|l|l|l|l|l|}
\hline Energy Use & Energy Prices & $\begin{array}{l}\text { Energy } \\
\text { Resources }\end{array}$ & $\begin{array}{l}\text { Technology } \\
\text { Improvement }\end{array}$ & $\begin{array}{l}\text { Distributed } \\
\text { Generation }\end{array}$ & Restructuring & $\begin{array}{l}\text { Environmental } \\
\text { Regulations }\end{array}$ \\
\hline & & & & $\mathrm{X}$ & $\mathrm{X}$ & \\
\hline
\end{tabular}

As part of a series of white papers, this study analyzes four possible scenarios of electricity restructuring for the purposes of developing a strategy for federally funded RD\&D to maintain and enhance electric system reliability.

Scenario One assumes a utility industry, which is vertically integrated but functionally unbundled, similar to what was recently assumed to occur in the United States during the next three-five years.

Scenarios Two and Three assume a movement toward regional transmission organizations (RTO). However, the two scenarios assume substantial differences in the organization and shape of the electricity markets they serve. Both scenarios rely on physical unbundling and trade of energy and reliability services using market mechanisms.

Scenario Four envisions increased reliance on small-scale generation, storage, and loadcontrol technologies. This would lead to generation from small-scale generators contributing 20 percent or more of total generation in some areas within a decade.

For each scenario, the need for federal RD\&D is evaluated and a rationale developed for the role of federal RD\&D. No model is utilized, and no energy quantities or prices are projected. Distributed generation is the focus of Scenario Four, but the scenario does not focus specifically on renewable energy technologies.

Time frame: $2000-2010$

Publication Date: December 1999 
16) Impact of Competitive Electricity Market on Renewable Generation Technology Choice and Policies in the United States

Publishing Organization: Ashok Sarkar, Renewable Energy 16 (1999).

\begin{tabular}{|l|l|l|l|l|l|l|}
\hline Energy Use & Energy Prices & $\begin{array}{l}\text { Energy } \\
\text { Resources }\end{array}$ & $\begin{array}{l}\text { Technology } \\
\text { Improvement }\end{array}$ & $\begin{array}{l}\text { Distributed } \\
\text { Generation }\end{array}$ & Restructuring & $\begin{array}{l}\text { Environmental } \\
\text { Regulations }\end{array}$ \\
\hline $\mathrm{X}$ & & & & & $\mathrm{X}$ & \\
\hline
\end{tabular}

This paper examines three scenarios of electricity market development: 1) reference case, 2 ) market power, and 3) competitive case. The author projects that in the "reference case," renewable generating capacity reaches 30 percent of the U.S. total by 2015 with about 10 percent of electricity generation coming from renewables. In the "competitive case," renewables penetrate the market at far lower levels, based on assumptions about fewer incentives for renewables. Renewables in the "competitive case" contribute only 10 percent of capacity by 2015, and produce about 5 percent of all electricity.

Emissions of SO2, NOx, and $\mathrm{CO} 2$ also are evaluated. Compared to the reference case, the competitive market case results in slightly lower emissions for all three pollutants. In the market power case, emissions of all three pollutants are projected to increase due to less incentive to generate less-polluting electricity. Distributed generation technologies are not specifically addressed in this scenario.

Time frame: $2001-\mathrm{N} / \mathrm{A}$

Publication Date: 2001

\section{Technology Forecasts}

These scenarios project future improvements in electricity-generating technologies and do not necessarily take into account the energy economy as a whole. Projections include forecasts on efficiency improvements and cost reductions. Some scenarios are separate reports or articles, while others are pulled from the broader energy economy scenarios listed above. For example, the EIA's annual Energy Outlook is listed as an Energy Economy scenario, but contains assumptions about the future development of generating technologies. The proprietary models do not openly publish their assumptions and, as such, cannot be included here.

\section{Annual Energy Outlook}

The EIA's assumptions for electricity-generating technologies are defined in the NEMS model, and more details are published in a separate EIA document ${ }^{3}$. Because the AEO is often seen as a reference or business-as-usual scenario, the assumptions for electricitygenerating technologies are likewise seen as "business as usual" with moderate gains in efficiencies and cost improvements.

\footnotetext{
3 Energy Information Administration, “Assumptions to the Annual Energy Outlook 2002,” DOE/EIA-0554 (2002), December 2001.
} 


\section{Scenarios for a Clean Energy Future}

While based on a modified version of the EIA's NEMS model, the CEF makes different assumptions about costs and efficiencies for renewable and nuclear electricity-generating technologies.

\section{Renewable Energy Technology Characterizations}

EPRI's technology characterizations ${ }^{4}$ make projections about the cost and efficiency of most renewable electricity-generating technologies. These include biomass, geothermal, solar, and wind power. Projections are made through 2030 in terms of efficiency improvements and all relevant costs.

Wind technology is projected to decline steadily in installed capacity cost. Larger turbines, economies of scale in production, and learning effects are expected to bring the installed cost of wind down substantially by 2030. The increasing operating and management $(\mathrm{O} \& \mathrm{M})$ costs for wind are due to increasing tower heights and more powerful wind regimes.

\section{Wind}

\begin{tabular}{|l|r|r|r|r|}
\hline & $\mathbf{2 0 0 5}$ & \multicolumn{2}{|c|}{$\mathbf{2 0 1 0}$} & \multicolumn{2}{|c|}{$\mathbf{2 0 2 0}$} & \multicolumn{2}{|c|}{$\mathbf{2 0 3 0}$} \\
\hline $\begin{array}{l}\text { Capital Cost } \\
(\$ / \mathrm{kW})\end{array}$ & 720 & 675 & 655 & 19.1 \\
\hline $\begin{array}{l}\text { O\&M } \\
(\$ / \mathrm{kW}-\mathrm{yr})\end{array}$ & 17.6 & 18.1 & 18.7 & \\
\hline
\end{tabular}

Biomass generation is projected to experience declining costs of technology over time. Integrated gasification combined-cycle generators are expected to experience the most rapid reductions in capital cost. Direct-fired combustion technology, which is more mature, is expected to decline in costs at a slower rate. By 2030, capital costs are projected to be equivalent for these two technologies.

\section{Biomass}

\begin{tabular}{|l|l|r|r|r|r|}
\hline & & \multicolumn{1}{|c|}{$\mathbf{2 0 0 5}$} & \multicolumn{1}{c|}{$\mathbf{2 0 1 0}$} & \multicolumn{1}{c|}{$\mathbf{2 0 2 0}$} & \multicolumn{1}{c|}{ 2030 } \\
\hline IGCC & $\begin{array}{l}\text { Capital Cost } \\
(\$ / \mathrm{kW})\end{array}$ & 1650 & 1464 & 1258 & 1111 \\
\hline & $\begin{array}{l}\text { Fixed O\&M } \\
(\$ / \mathrm{kW}-\mathrm{yr})\end{array}$ & 43.4 & 43.4 & 43.4 & 43.4 \\
\hline $\begin{array}{l}\text { Direct } \\
\text { Fired }\end{array}$ & $\begin{array}{l}\text { Capital Cost } \\
(\$ / \mathrm{kW})\end{array}$ & 1510 & 1346 & 1115 & 1115 \\
\hline & $\begin{array}{l}\text { Fixed O\&M } \\
(\$ / \mathrm{kW}-\mathrm{yr})\end{array}$ & 60 & 60 & 49 & 49 \\
\hline & & & & & \\
\hline
\end{tabular}

\footnotetext{
${ }^{4}$ Electric Power Research Institute and U.S. Department of Energy, "Renewable Energy Technology Characterizations," TR-109496, December 1997.
} 
Solar technologies encompass a diverse set of technologies, which include photovoltaics, solar thermal used in power towers, parabolic troughs, and dish engines. While all solar technologies are expected to experience lower installed costs, the most dramatic reduction in costs is for photovoltaic technologies, which are projected to decline by about 60-75 percent between 2005 and 2030 .

\begin{tabular}{|c|c|c|c|c|c|}
\hline \multicolumn{6}{|l|}{ Solar } \\
\hline & & 2005 & 2010 & 2020 & 2030 \\
\hline \multirow[t]{2}{*}{$\begin{array}{l}\text { C-Si } \\
\text { Residential }\end{array}$} & $\begin{array}{l}\text { Capital Cost } \\
(\$ / k W)\end{array}$ & 4040 & 3050 & 1770 & 1040 \\
\hline & $\begin{array}{l}\text { O\& M } \\
(\$ / k W-y r)\end{array}$ & 14.3 & 13.3 & 12.5 & 11.8 \\
\hline \multirow[t]{2}{*}{$\begin{array}{l}\text { Thin-film } \\
\text { utility }\end{array}$} & $\begin{array}{l}\text { Capital Cost } \\
(\$ / k W)\end{array}$ & 2900 & 1500 & 1111 & 880 \\
\hline & $\begin{array}{l}\text { O\&M } \\
\text { (\$/k/W-yr) }\end{array}$ & 5.8 & 3.6 & 2.4 & 2.3 \\
\hline \multirow[t]{2}{*}{ Solar Tower } & $\begin{array}{l}\text { Capital Cost } \\
(\$ / \mathrm{kW})\end{array}$ & 2329 & 2605 & 2523 & 2523 \\
\hline & $\$ / \mathrm{kW}-\mathrm{yr}$ & 23 & 30 & 25 & 25 \\
\hline \multirow[t]{2}{*}{$\begin{array}{l}\text { Parabolic } \\
\text { trough }\end{array}$} & $\begin{array}{l}\text { Capital Cost } \\
(\$ / \mathrm{kW})\end{array}$ & 2916 & 2999 & 2907 & 2756 \\
\hline & & 52 & 43 & 34 & 34 \\
\hline \multirow[t]{2}{*}{ Dish Engine } & $\begin{array}{l}\text { Capital Cost } \\
(\$ / \mathrm{kW})\end{array}$ & 3231 & 1690 & 1467 & 1324 \\
\hline & $\begin{array}{l}\text { O\&M } \\
(\mathrm{c} / \mathrm{kWh})\end{array}$ & 2.3 & 1.1 & 1.05 & 1.05 \\
\hline
\end{tabular}

Geothermal technology costs are expected to decline over time. Hydrothermal generation, which is more established, is expected to see a slow decline in capital costs. The newer hot dry rock technologies are expected to see a more dramatic reduction in capital cost, with installed cost falling more than 50 percent between 2005 and 2030.

\section{Geothermal}

\begin{tabular}{|l|l|r|r|r|r|}
\hline & \multicolumn{1}{|c|}{$\mathbf{2 0 0 5}$} & \multicolumn{1}{|c|}{$\mathbf{2 0 1 0}$} & \multicolumn{1}{|c|}{$\mathbf{2 0 2 0}$} & \multicolumn{1}{|c|}{$\mathbf{2 0 3 0}$} \\
\hline Hydrothermal & $\begin{array}{l}\text { Capital Cost } \\
(\$ / \mathrm{kW})\end{array}$ & 1250 & 1194 & 1100 & 1036 \\
\hline & $\begin{array}{l}\text { O\&M } \\
(\$ / \mathrm{kW}-\mathrm{yr})\end{array}$ & 74.8 & 66.3 & 58.2 & 54.7 \\
\hline Hot dry rock & $\begin{array}{l}\text { Capital Cost } \\
(\$ / \mathrm{kW})\end{array}$ & 4756 & 4316 & 3276 & 2692 \\
\hline & $\begin{array}{l}\text { O\&M } \\
(\$ / \mathrm{kW}-\mathrm{yr})\end{array}$ & 191 & 179 & 163 & 152 \\
\hline
\end{tabular}




\section{EPIA}

The EPIA scenario ${ }^{5}$ projects that ready-to-install PV modules will decrease in cost from current levels of about $\$ 3$ per Watt peak (Wp) to less than $\$ 1$ per Wp in 2020. This will be due, in part, to improved efficiencies in production and a shift toward cheaper thinfilm technologies.

\section{Distributed Generation Scenarios}

The emergence of distributed generation as an alternative to the traditional central plant system offers new opportunities for renewable energy technologies. Some renewable energy technologies like solar and wind offer the ability to place power generation in smaller units dispersed widely over an area. The following scenarios focus on future developments of distributed generation systems.

Can We Have Our Cake and Eat It Too? Creating Distributed Generation

Technology to Improve Air Quality.

Publishing Organization: The Energy Foundation

\begin{tabular}{|l|l|l|l|l|l|l|}
\hline Energy Use & Energy Prices & $\begin{array}{l}\text { Energy } \\
\text { Resources }\end{array}$ & $\begin{array}{l}\text { Technology } \\
\text { Improvement }\end{array}$ & $\begin{array}{l}\text { Distributed } \\
\text { Generation }\end{array}$ & Restructuring & $\begin{array}{l}\text { Environmental } \\
\text { Regulations }\end{array}$ \\
\hline & & & & $\mathrm{X}$ & & $\mathrm{X}$ \\
\hline
\end{tabular}

While this scenario does not specify any timeline, it makes qualitative projections of distributed generation's (DG) contribution to the energy system. DG has the potential to improve energy security and may decrease air pollution, although the outcome is uncertain given the current regulatory framework.

DG technologies are expected to compete with central station combined-cycle generators rather than existing coal-fired generators. The most cost-effective, currently available DG technologies - diesel and gas internal combustion engines - are also the most polluting. The report concludes that only DG technologies with the lowest emissions levels and significant recovery of waste heat can be competitive with combined-cycle central station generators, if air pollution is taken into consideration.

The scenario only covers fossil-fueled technologies and different types of fuel cells. Renewables are not mentioned.

Time frame: $2000-\mathrm{N} / \mathrm{A}$

Publication Date: December 1, 2000

\footnotetext{
${ }^{5}$ Greenpeace/European Photovoltaic Industry Association (EPIA), "Solar Generation: electricity for over 1 billion people and 2 million jobs by 2020," 2000.
} 
Cleaner Energy, Greener Profits - Fuel Cells as Cost-Effective Distributed Energy

Resources.

Publishing Organization: Rocky Mountain Institute

\begin{tabular}{|l|l|l|l|l|l|l|}
\hline Energy Use & Energy Prices & $\begin{array}{l}\text { Energy } \\
\text { Resources }\end{array}$ & $\begin{array}{l}\text { Technology } \\
\text { Improvement }\end{array}$ & $\begin{array}{l}\text { Distributed } \\
\text { Generation }\end{array}$ & Restructuring & $\begin{array}{l}\text { Environmental } \\
\text { Regulations }\end{array}$ \\
\hline & & & & $\mathrm{X}$ & & $\mathrm{X}$ \\
\hline
\end{tabular}

This scenario discusses qualitatively the benefits and values of distributed generation (DG) and fuel cells for the U.S. energy economy.

The report discusses several areas of value that may or may not be taken into account in the conventional electric-utility system. In addition to the conventional energy value, fuel cells also can provide thermal energy value. Waste heat recovery can provide fuel savings of $\$ 100-\$ 150 / \mathrm{kW}$-year. Modular DG also offers option value that reduces the cost of overbuilding - this value is estimated at $\$ 50-\$ 200 / \mathrm{kW}$-year with modularity. A deferral value of $\$ 50-\$ 200 / \mathrm{kW}$-year is possible as DG can be built in smaller, modular systems. Packaged DG offers engineering cost savings of $\$ 50-\$ 150 / \mathrm{kW}$-year and T\&D loss reductions of $\$ 25 / \mathrm{kW}$-year. Modern society's demand for reliability makes outages expensive, and the reliability value is estimated to be between $\$ 25-\$ 250 / \mathrm{kW}$-year. Finally, DG fuel cells offer environmental value. Fuel cells' low emissions rates make them easier to site compared to other DG technologies. These values may not necessarily be additive.

The scenario does not discuss renewable energy technologies.

Time frame: $2000-\mathrm{N} / \mathrm{A}$

Publication Date: 2002

On Future Fuels: A Comparison of Options.

Publishing Organization: Thomas, C.E., Directed Technologies, Inc., Arlington, VA, 2001.

\begin{tabular}{|l|l|l|l|l|l|l|}
\hline Energy Use & Energy Prices & $\begin{array}{l}\text { Energy } \\
\text { Resources }\end{array}$ & $\begin{array}{l}\text { Technology } \\
\text { Improvement }\end{array}$ & $\begin{array}{l}\text { Distributed } \\
\text { Generation }\end{array}$ & Restructuring & $\begin{array}{l}\text { Environmental } \\
\text { Regulations }\end{array}$ \\
\hline & & & & $\mathrm{X}$ & & $\mathrm{X}$ \\
\hline
\end{tabular}

This paper discusses the current and near-future options for fuels in transportation and stationary electricity generation focusing on fuel cells. The paper examines scenarios of different production levels of fuel cells units and different levels of natural gas fuel prices.

The cost of a fuel cell system is projected to fall with increased levels of production. While producing one fuel cell unit is projected to cost $\$ 4,002 / \mathrm{kW}$, producing 100 units reduces this to $\$ 1,701 / \mathrm{kW}$; and at 10,000 units, the capacity cost is $\$ 778 / \mathrm{kW}$. Cost reductions are estimated only with respect to scale of output, no time frame is given. 
Production of electricity (and electricity and heat) using fuel cells results in a negative after-tax return on investment at production levels of 10,000 units. However, oversizing the reformer and producing extra hydrogen for use in transportation or industry can achieve coproduction of hydrogen. The prospect of generating electricity and producing hydrogen, as well as combining electricity generation with heat recovery and hydrogen production, offers the possibility of a positive return on investment at production levels of 10,000 units.

Longer term, the greatest opportunities lie in storage for intermittent renewable technologies. This study claims that renewable generating expansion beyond 10 to 20 percent of the grid capacity will require some form of energy storage.

Time frame: $2000-\mathrm{N} / \mathrm{A}$

Publication Date: 2000

Biomass pyrolysis for power generation - a potential technology.

Publishing Organization: Anuradda Ganesh and Rangan Banerjee, Renewable Energy $22(2001)$

\begin{tabular}{|l|l|l|l|l|l|l|}
\hline Energy Use & Energy Prices & $\begin{array}{l}\text { Energy } \\
\text { Resources }\end{array}$ & $\begin{array}{l}\text { Technology } \\
\text { Improvement }\end{array}$ & $\begin{array}{l}\text { Distributed } \\
\text { Generation }\end{array}$ & Restructuring & $\begin{array}{l}\text { Environmental } \\
\text { Regulations }\end{array}$ \\
\hline & & & $\mathrm{X}$ & & & $\mathrm{X}$ \\
\hline
\end{tabular}

This paper discusses the potential for biomass pyrolysis in electricity power generation. Four alternative technology paths are evaluated: 1) Biomass Combustion - Rankine Cycle, 2) Biomass Gasification - Gas Engine, 3) Biomass Gasification - Combined Cycle, 4) Biomass Pyrolysis - Combined Cycle. The generators evaluated are in the 1 to 5 MW range.

The four different technology paths are evaluated for capital costs, capacity factors, and biomass fuel costs. Using a low and high range for technology costs, all four technologies result in comparable delivered electricity costs. For the low cost set with a 90 percent capacity factor, costs range from $3.8 \mathrm{c} / \mathrm{kWh}$ (biomass gasification-gas engine) to $4.8 \mathrm{c} / \mathrm{kWh}$ (biomass pyrolysis-combined cycle).

Time frame: $2001-\mathrm{N} / \mathrm{A}$

Publication Date: 2001

Engines versus electrons: the future of power production

Publishing Organization: D E Winterbone, Proceedings of the Institution of Mechanical Engineers, Vol. 214 Part A

\begin{tabular}{|l|l|l|l|l|l|l|}
\hline Energy Use & Energy Prices & $\begin{array}{l}\text { Energy } \\
\text { Resources }\end{array}$ & $\begin{array}{l}\text { Technology } \\
\text { Improvement }\end{array}$ & $\begin{array}{l}\text { Distributed } \\
\text { Generation }\end{array}$ & Restructuring & $\begin{array}{l}\text { Environmental } \\
\text { Regulations }\end{array}$ \\
\hline & & & $\mathrm{X}$ & & & \\
\hline
\end{tabular}

This paper discusses the theoretical and practical limits of efficiencies of electricitygenerating technologies. Both heat engines and fuel cells are evaluated. 
While the most efficient gas turbine plants currently have efficiencies of $21.1-32.5$ percent, the combined-cycle plants have efficiencies ranging from 42.5 to 58.5 percent. The author projects that efficiencies of more than 60 percent are attainable for combinedcycle plants. Fuel cells appear to have an advantage over heat engines when the plant operates for a significant time with a low load, as fuel cells are more efficient at lower loads than at higher loads.

\section{Time frame: $2000-\mathrm{N} / \mathrm{A}$}

Publication Date: 2000

Some projections were not included due to the high cost of the publications. They are listed here with the relevant summary data provided in the open literature.

"Fuel Cell Industry Review," by Business Communications Company, Inc., projects that $130 \mathrm{GW}$ of new fuel cell power-generating capacity will be in place in the United States. by 2010. (April 2001).

"Fuel Cells," by The Freedonia Group, projects that the U.S. market for fuel cells will be valued at $\$ 2.4$ billion by 2004 and increase to $\$ 7$ billion by 2009. (May 2000).

"Micropower," by The Freedonia Group, projects the market for micropower products to reach $\$ 6.1$ billion in 2005 .

"Opportunities in Advanced Fuel Cell Technologies: Stationary Power Generation 19982008," by Kine \& Company, projects that between 2.5 and $6 \mathrm{GW}$ of fuel cell-generating capacity will be in place by 2010. (June 1998).

\section{Global Scenarios}

In addition to the domestic and technology scenarios already covered, there are several global scenarios, many focusing on climate change ${ }^{6}$. These scenarios do not cover individual countries such as the United States explicitly, but rather group them together into larger regions. The United States often is grouped into a North American region. Some of these scenarios go further out into the future than the domestic scenarios already covered - some as far as 2100 . There appears to be a trade-off between the number of years the scenario covers, regions, and technology detail.

Renewable energy sources are rarely represented in a detailed manner in these global scenarios. None of these global scenarios focuses explicitly on distributed generation. While there is perhaps a wider range of scenario outcomes in many of the scenarios associated with global climate change (as with the domestic scenarios), there are no real discrete event "surprise" scenarios.

\footnotetext{
${ }^{6}$ IIASA/WEC, "Global Energy Perspectives; Shell, "The Evolution of the World's Energy System 18602060"; IEA, "World Energy Outlook"; DOE/EIA "International Energy Outlook"; IPCC "WGIII", John P. Weyant, editor, The Costs of the Kyoto Protocol: A Multi-Model Evaluation, special issue of The Energy Journal, 2000.
} 


\section{Scenario Comparisons}

\section{Summary of Aggregate Energy Consumption}

The different scenarios are fairly consistent in the near term, although differences increase over time. None of the U.S. scenarios make projections of domestic energy consumption beyond 2020 (Table 1).

Table 1: Summary of Energy Consumption (quadrillion Btu)

\begin{tabular}{|c|c|c|c|c|}
\hline Scenario & 2005 & 2010 & 2015 & 2020 \\
\hline 1) EIA - AEO2002* & 107.6 & 115.6 & 123.6 & 130.8 \\
\hline 3) EIA-Nat Gas Mrkt. & 107.61 & 115.61 & 123.64 & 130.85 \\
\hline $\begin{array}{l}\text { 4) EIA-Accelerated } \\
\text { Depletion }\end{array}$ & $\begin{array}{r}105.08- \\
105.15\end{array}$ & $111.29-111.54$ & $116.24-116.68$ & $119.78-121.00$ \\
\hline $\begin{array}{l}\text { 5) EIA-Emissions } \\
\text { Control }\end{array}$ & $\begin{array}{r}104.07- \\
107.56\end{array}$ & $107.32-114.74$ & $111.33-121.34$ & $115.18-127.68$ \\
\hline 6) $\mathrm{CEF}$ & & $103.3-110.2$ & & $100.9-119.4$ \\
\hline 7) GRI & 103.5 & 111.4 & & 117.7 \\
\hline $\begin{array}{l}\text { 9) UCS Clean Energy } \\
\text { Blueprint }\end{array}$ & & 105.3 & & 102.5 \\
\hline 13) IPAA & 102.96 & 103.96 & 116.26 & \\
\hline 14) AGA & & & & $115.2-122.6$ \\
\hline
\end{tabular}

For renewable energy, most scenarios are fairly consistent in the near term, with differences widening over time (Table 2). Scenarios not listed did not report values.

Table 2: Summary of Renewable Energy Consumption (quadrillion Btu)

\begin{tabular}{|c|c|c|c|c|}
\hline Scenario & 2005 & 2010 & 2015 & 2020 \\
\hline $\begin{array}{l}\text { 1) EIA - AEO2002 } \\
\text { Total } \\
\text { Non-hydro }\end{array}$ & $\begin{array}{l}7.57 \\
4.45\end{array}$ & $\begin{array}{l}8.10 \\
4.99\end{array}$ & $\begin{array}{l}8.70 \\
5.59\end{array}$ & $\begin{array}{l}9.17 \\
6.07\end{array}$ \\
\hline $\begin{array}{l}\text { 4) EIA-Accelerated } \\
\text { Depletion } \\
\text { Total } \\
\text { Non-hydro }\end{array}$ & $\begin{array}{r}7.09-7.10 \\
n / a\end{array}$ & $\begin{array}{r}7.43 \\
n / a\end{array}$ & $\begin{array}{r}7.71-7.72 \\
n / a\end{array}$ & $\begin{array}{r}7.99-8.06 \\
n / a\end{array}$ \\
\hline $\begin{array}{l}\text { 5) EIA-Emissions } \\
\text { Control } \\
\text { Total } \\
\text { Non-hydro }\end{array}$ & $\begin{array}{l}7.27-8.78 \\
4.17-5.68\end{array}$ & $\begin{array}{l}8.05-9.95 \\
4.95-6.84\end{array}$ & $\begin{array}{r}8.35-10.37 \\
5.26-7.27\end{array}$ & $\begin{array}{r}8.58-10.88 \\
5.50-7.79\end{array}$ \\
\hline $\begin{array}{l}\text { 6) CEF } \\
\text { Total } \\
\text { Non-hydro }\end{array}$ & & $\begin{array}{r}7.8-10.2 \\
4.5-6.9\end{array}$ & & $\begin{array}{r}8.9-11.3 \\
5.6-8.0\end{array}$ \\
\hline $\begin{array}{l}\text { 7) GRI } \\
\text { Total } \\
\text { Non-hydro }\end{array}$ & $\begin{array}{l}7.5 \\
4.1\end{array}$ & $\begin{array}{l}8.6 \\
5.1\end{array}$ & $\begin{array}{l}9.1 \\
5.6\end{array}$ & \\
\hline $\begin{array}{l}\text { 9) UCS Clean Energy } \\
\text { Blueprint } \\
\text { Total } \\
\text { Non-hydro }\end{array}$ & & $\begin{array}{r}7.5-11.5 \\
4.4-8.4\end{array}$ & & $\begin{array}{l}8.0-13.7 \\
4.9-10.6\end{array}$ \\
\hline $\begin{array}{l}\text { 13) IPAA* } \\
\text { Total } \\
\text { Non-hydro }\end{array}$ & $\begin{array}{r}3.62 \\
n / a\end{array}$ & $\begin{array}{r}3.62 \\
n / a\end{array}$ & $\begin{array}{r}3.87 \\
n / a\end{array}$ & \\
\hline $\begin{array}{l}\text { 14) AGA } \\
\text { Total } \\
\text { Non-hydro }\end{array}$ & & & & $\begin{array}{l}8.9 \\
n / a\end{array}$ \\
\hline
\end{tabular}


Natural gas prices show variation among the scenarios as well as differences in trends over time. GRI indicates a downward trend while several others show an upward trend.

Table 3: Summary of Natural Gas Wellhead Prices (\$ per thousand cubic feet).

\begin{tabular}{|l|r|r|r|r|}
\hline \multicolumn{1}{|c|}{ Scenario } & \multicolumn{1}{c|}{$\mathbf{2 0 0 5}$} & $\mathbf{2 0 1 0}$ & \multicolumn{1}{c|}{$\mathbf{2 0 1 5}$} & \multicolumn{1}{c|}{$\mathbf{2 0 2 0}$} \\
\hline 1) EIA-AEO2002 & 2.67 & 2.86 & 3.08 & 3.28 \\
\hline 2) EIA-RPS & $2.40-2.48$ & $2.48-2.62$ & $2.68-3.13$ & $2.79-4.12$ \\
\hline 3) EIA-Nat Gas Mrkt. & $2.64-2.66$ & $2.72-2.85$ & & $3.14-3.26$ \\
\hline $\begin{array}{l}\text { 4) EIA-Accelerated } \\
\text { Depletion }\end{array}$ & $2.47-2.55$ & $2.55-2.69$ & $2.76-3.22$ & $2.87-4.24$ \\
\hline $\begin{array}{l}\text { 5) EIA-Emissions } \\
\text { Control }\end{array}$ & $2.92-3.07$ & $2.46-3.37$ & $2.36-3.30$ & $2.27-3.63$ \\
\hline 6) CEF & & $4.06-4.86$ & & $3.81-4.43$ \\
\hline 7) GRI & 2.13 & 2.09 & & 2.06 \\
\hline 14) AGA & & & & $2.75-3.75$ \\
\hline
\end{tabular}

All prices in year 2000 dollars.

\section{Renewable Technology Characteristics}

Conventional and renewable energy technologies have very different capital cost and efficiency attributes. Both renewable and conventional energy technologies are projected to improve over time both in terms of capital cost and efficiency. Renewables were covered earlier under: Renewable Energy Technology Characterizations, and conventional technologies are detailed below in Table 4.

Table 4: Conventional and fossil-fueled technologies

\begin{tabular}{|l|l|l|}
\hline Technology & $\begin{array}{l}\text { Capital cost } \\
(\$ / \mathrm{kW})\end{array}$ & $\begin{array}{l}\text { Heat Rate } \\
(\mathrm{Btu} / \mathrm{KWh})\end{array}$ \\
\hline Pulverized Coal & & \\
\hline 2005 & 1110 & 9253 \\
\hline 2010 & 1083 & 9087 \\
\hline 2015 & $1062-1068$ & 9087 \\
\hline 2020 & $1047-1056$ & 9087 \\
\hline Coal-ICGG & & \\
\hline 2005 & $1208-1332$ & $7469-7769$ \\
\hline 2010 & $1000-1332$ & $6968-7769$ \\
\hline 2015 & $976-1332$ & $6968-7769$ \\
\hline 2020 & $951-1332$ & $6968-7769$ \\
\hline Conv. Combined Cycle & & \\
\hline 2005 & 453 & 7343 \\
\hline 2010 & 448 & 7000 \\
\hline 2015 & 443 & 7000 \\
\hline 2050 & 438 & 7000 \\
\hline Adv. Combined Cycle & & \\
\hline 2005 & $572-587$ & $6639-6812$ \\
\hline 2010 & $516-587$ & $5672-6812$ \\
\hline 2015 & $499-587$ & $4960-6812$ \\
\hline 2020 & $485-587$ & $4960-6812$ \\
\hline Conv. Combustion Turbine & & \\
\hline 2005 & 336 & 11033 \\
\hline 2010 & 333 & 10600 \\
\hline 2015 & 329 & 10600 \\
\hline 2020 & 326 & 10600 \\
\hline & & \\
\hline & & \\
\hline
\end{tabular}




\begin{tabular}{|l|l|l|}
\hline Adv. Combustion Turbine & & \\
\hline 2005 & $446-472$ & $8117-8907$ \\
\hline 2010 & $384-472$ & $6800-8907$ \\
\hline 2015 & $363-472$ & $6800-8907$ \\
\hline 2020 & $361-472$ & $6800-8907$ \\
\hline Adv. Nuclear & & \\
\hline 2005 & $1650-2108$ & \\
\hline 2010 & $1484-2063$ & \\
\hline 2015 & $1320-2019$ & \\
\hline 2020 & $1320-1974$ & \\
\hline Distributed Generators & & \\
\hline $2000-$ Peak & 531 & \\
\hline 2000 -Baseload & 591 & \\
\hline $2010-$ Peak & 440 & \\
\hline $2010-$ Baseload & 560 & \\
\hline Micro turbine* & & \\
\hline 2000 & $450-1,000$ & $8,123-11,765$ \\
\hline Fuel Cells* & & \\
\hline 2000 & $3,750-5,000$ & $5,986-8,530$ \\
\hline IC Engine* & & \\
\hline 2000 & $200-350$ & 9,748 \\
\hline & & \\
\hline
\end{tabular}

Sources: Energy Information Administration, Assumptions to the Annual Energy Outlook 2002, 2002.

*Ann-Marie Borbely and Jan F. Kreider, "Distributed Generation, The Power Paradigm for the New Millennium," 2001.

\section{Conclusions}

This report surveyed scenarios of markets and technologies that could impact renewable electricity-generating technologies during the next 20-100 years in the United States. The scenarios presented in this report are fairly consistent in the near term but diverge more dramatically in the outer years of the scenarios. Most scenarios are incremental variations around the same theme. There are no "surprise" scenarios where future development of the energy economy takes unexpected directions.

The most commonly used model for developing scenarios is the EIA's National Energy Modeling System (NEMS). Many scenarios rely on modified versions of NEMS or use results from NEMS to calibrate or initiate other models.

Distributed generation is rarely mentioned specifically and appears to be an area in need of more detailed scenario analysis. Renewable energy is usually included in those scenarios developed using the NEMS or POEMS model. Other scenarios generally either exclude renewable energy or represent only a subset of the renewable energy technologies, though sometimes one or two renewable technologies are aggregated. 


\section{REPORT DOCUMENTATION PAGE}

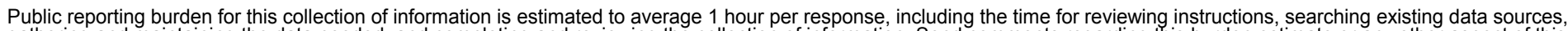

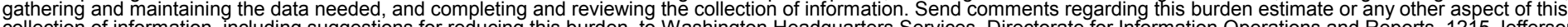

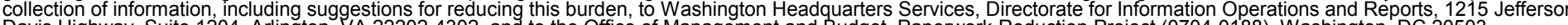
Davis Highway, Suite 1204, Arlington, VA 22202-4302, and to the Office of Management and Budget, Paperwork Reduction Project (0704-0188), Washington, DC 20503.
1. AGENCY USE ONLY (Leave blank)
2. REPORT DATE January 2003
3. REPORT TYPE AND DATES COVERED
Technical Report - Analysis

\section{TITLE AND SUBTITLE \\ Domestic Energy Scenarios}

5. FUNDING NUMBERS

6. $\operatorname{AUTHOR}(\mathrm{S})$

J. Aabakken and W. Short

TA: AS72.1502

7. PERFORMING ORGANIZATION NAME(S) AND ADDRESS(ES) National Renewable Energy Laboratory

8. PERFORMING ORGANIZATION 1617 Cole Blvd.

Golden, CO 80401-3393

9. SPONSORING/MONITORING AGENCY NAME(S) AND ADDRESS(ES)

National Renewable Energy Laboratory

1617 Cole Blvd.

Golden, CO 80401-3393

\author{
REPORT NUMBER
}

11. SUPPLEMENTARY NOTES

12a. DISTRIBUTION/AVAILABILITY STATEMENT

National Technical Information Service

U.S. Department of Commerce

5285 Port Royal Road

Springfield, VA 22161 12b. DISTRIBUTION CODE

10. SPONSORING/MONITORING AGENCY REPORT NUMBER

NREL/TP-620-32742

13. ABSTRACT (Maximum 200 words)

This report attempts to organize and evaluate scenarios of markets and technologies that could impact renewable and distributed electricity-generating technologies during the next 20-100 years in the United States. For the purposes of this report, scenarios are defined broadly as any projection or forecast that helps illuminate the potential of Renewable Electric Technologies (RETs) in the United States. Scenarios vary widely in terms of their scope-some focus on supply of fuels or narrow segments of markets with limited timeframes, while others are broader in scope and time span. There are several factors that influence the market penetration of renewable energy and distributed generation technologies. Most notable among these are natural gas prices, technology improvements, and policy measures. Natural gas prices are important because most new generating capacity, as well as marginal generation units, generally are natural-gas fired. Assumptions about the rate of improvement in renewable and distributed generation technologies can also have a significant impact on market penetration. Finally, policy measures that support these technologies, such as tax credits or interconnection standards, can contribute to their accelerated adoption.

14. SUBJECT TERMS

domestic energy scenarios; renewable energy technologies; distributed-generation development; natural gas prices; tax credits; policy measures; environmental regulations; restructuring; energy security; National Energy Modeling System; Energy Information Administration; emissions; electric power; Scenarios for a Clean Energy Future; Union of Concerned Scientists; Economic Policy Institute; Center for a Sustainable Economy

17. SECURITY CLASSIFICATION OF REPORT

Unclassified
18. SECURITY CLASSIFICATION OF THIS PAGE Unclassified
19. SECURITY CLASSIFICATION OF ABSTRACT Unclassified
15. NUMBER OF PAGES

16. PRICE CODE

20. LIMITATION OF ABSTRACT

UL 